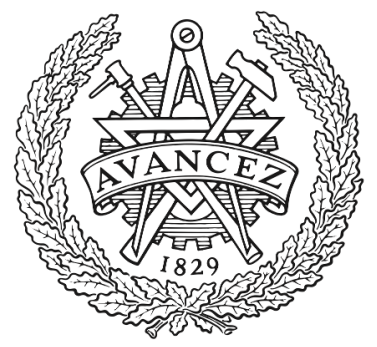

CHALMERS

UNIVERSITY OF TECHNOLOGY

\title{
Optimization of process parameters for mechanical extraction of banana juice using response surface methodology
}

Downloaded from: https://research.chalmers.se, 2023-04-26 15:16 UTC

Citation for the original published paper (version of record):

Majaliwa, N., Kibazohi, O., Alminger, M. (2019). Optimization of process parameters for mechanical extraction of banana juice using response

surface methodology. Journal of Food Science and Technology, 56(9): 4068-4075.

http://dx.doi.org/10.1007/s13197-019-03875-7

N.B. When citing this work, cite the original published paper. 


\title{
Optimization of process parameters for mechanical extraction of banana juice using response surface methodology
}

\author{
Nuria Majaliwa $^{1,2} \cdot$ Oscar Kibazohi $^{1} \cdot$ Marie Alminger $^{2}$
}

Revised: 7 June 2019/ Accepted: 12 June 2019

(C) Association of Food Scientists \& Technologists (India) 2019

\begin{abstract}
Banana juice is traditionally processed under very basic conditions characterized by low efficiency and poor hygiene. Introduction of mechanical pressing has created opportunities for upgrading banana juice production, but more knowledge is needed about critical factors for juice release and about optimizing extraction for higher yield and quality. This study sought to identify and optimize important factors associated with juice release. This was done using an experimental design (Box-Behnken design of response surface methodology) involving three levels of three independent variables: blending speed (1000-3500 rpm), extraction time (30-240 s), and stage of ripeness (3-7). A second-order polynomial equation was created to describe the relationship between dependent and independent variables. The results showed that juice yield increased with blending speed, extraction time, and stage of ripeness, whereas the quadratic (squared) effect of these factors was a significant decrease in juice yield. Optimum juice yield $(57.5 \%)$ was obtained at blending speed $2650 \mathrm{rpm}$, extraction time $162 \mathrm{~s}$, and ripeness stage 5 . Analysis of variance showed that stage of ripeness significantly $(p \leq 0.001)$ affected juice yield. This novel information on the underlying factors in banana juice extraction and on optimization of the process can be used to improve mechanical extraction of low-viscosity, clear banana juice and achieve scaling-up of banana juice processing.
\end{abstract}

Nuria Majaliwa

nurimajor@yahoo.co.uk

1 Department of Chemical and Mining Engineering, University of Dar es Salaam, P.O. Box 35131, Dar es Salaam, Tanzania

2 Department of Biology and Biological Engineering, Chalmers University of Technology, 41296 Göteborg, Sweden
Keywords Banana juice - Mechanical juice extraction . Optimization · Response surface methodology

\section{Introduction}

Globally, fresh bananas are mostly consumed in cooking dishes, roasted, in desserts, or processed into juice and wine (Mohapatra et al. 2010; Trust 2012). In Tanzania, bananas are staple food for a large segment of the population (Pedersen 2012), but post-harvest losses of bananas are a problem, with on average 135,158 metric tons lost per year (Net 2018). In sub-Saharan Africa as a whole, postharvest losses of bananas are estimated to be around 30\% (Affognon et al. 2015). Limited knowledge of post-harvest treatments and of suitable processing methods for bananas is a major cause of these high losses (Adeniji et al. 2010).

It is therefore important to develop efficient technologies for use in creating new value chains for banana products such as juice, snacks, and powders (Mohapatra and Mishra 2011; Palmer 1979). Moreover, identification of solutions for extending the shelf-life and reducing postharvest losses of banana products would be of great commercial interest. Within the banana value chain, banana juice extraction is one way of reducing the losses. Worldwide, banana juice is produced at commercial level by either enzymatic or mechanical extraction. Use of pectinolytic enzymes in production of banana juice gives maximum yield (50-65\%) and products with good aroma (Kumar 2015). In contrast, mechanical extraction gives low yield (38.1\%) (Viquez et al. 1981) and involves addition of polyethylene strips for improvement of rheological properties (Kyamuhangire 1998). Moreover, although enzymatic methods produce higher banana juice yield, consumption of energy in the process is high, resulting in 
higher production costs than with mechanical methods (Landbo et al. 2007; Tapre and Jain 2014). Furthermore, application of enzymatic methods requires a high level of technical skills that are unavailable within small-scale processing.

In East Africa, low-viscosity clear banana juice is produced locally using a traditional process of macerating a mixture of ripe bananas and spear grass with the hands or feet, which makes the process non-hygienic and rudimentary (Byarugaba-Bazirake 2008). Due to these challenges, there is limited commercial production of low-viscosity clear banana juice. The hygiene standard of the traditional method has been improved by replacement of spear grass with polyethylene strips (Kyamuhangire et al. 2002), although in a recent study banana juice was released with an estimated yield of $58 \%$ without the use of spear grass or polyethylene strips (Kibazohi et al. 2017). The traditional process is purely mechanical and does not involve use of enzymes or hot water (Kibazohi et al. 2017; Kyamuhangire 1990). However, there are still occasional juice extraction failures, for unknown reasons (Kyamuhangire and Pehrson 1997; Kyamuhangire et al. 2002).

There is little information available in the literature on the main processing parameters affecting banana juice release. Some studies have examined enzymatic processing of banana juice and optimization of that process (IbarraJunquera et al. 2014; Lee and Yusof 2006; Sagu et al. 2014), but no previous study has focused on exploration and optimization of processing conditions using mechanical pressing.

The aims of the present study were twofold: (1) to explore and identify the most significant factors associated with banana juice release during mechanical pressing; and (2) to optimize these processing factors for juice yield using response surface methodology (RSM).

\section{Materials and methods}

\section{Raw material}

Banana fruits (Pisang Awak, genotype Mbile-AAA-EA) were purchased at the local market in Dar es Salaam, Tanzania, and allowed to ripen for 5 days at $28-32{ }^{\circ} \mathrm{C}$ atmospheric temperature and $95-100 \%$ relative humidity in the laboratory. Stage of ripeness of banana fruits was categorized as follows, using a color index developed by USDA (2001): Stage 1 = Fully green. 2 = Mostly green, with some yellow spots. $3=$ More green than yellow . $4=$ More yellow than green. $5=$ Yellow with some green at the end of the fruit. $6=$ Yellow overall. $7=$ Yellow overall with brown specks (Fig. 1).

\section{Banana juice extraction}

Banana juice extraction was performed by mechanical pressing using a variable speed blender (Blixer 4 V.V., Robot Coupe, and France) with capacity 4.5 L. Ripened bananas were washed, peeled, and cut into slices. Before juice extraction, $500 \mathrm{~g}$ banana slices were weighed out and processed to a pulp in the blender. In the present experiment, different combinations of ripening stage $(3,5$, and 7 color), blending speed $(1000,2250$, and $3500 \mathrm{rpm})$, and extraction time $(30,135$, and $240 \mathrm{~s})$ were tested in a series of randomized runs. The resulting juice was hand squeezed out and separated from the pulp using a piece of white muslin and juice yield from the fresh sample was calculated as:

$\mathrm{Y}(\%)=\frac{\mathrm{W} 1-\mathrm{W} 2}{\mathrm{~W} 1} \times 100 \%$

where $\mathrm{Y}$ is juice yield, $\mathrm{W} 1$ is weight of banana pulp (i.e., $500 \mathrm{~g}$ wet weight) and W2 is weight of banana waste (also in $\mathrm{g}$ wet weight).

\section{Experimental design and statistical analysis}

Using Design Expert Software Version 11, a total of 17 experimental runs with five center points and using different combinations of the independent variables (blending speed, extraction time, stage of ripeness) were designed, as presented in Table 1. The significance of each factor on the response (yield) was determined by analysis of variance (ANOVA). Each independent variable was assigned three levels $(-1,0$, and 1$)$, which were selected based on preliminary experiments, and runs were randomized to minimize external variation (see Table 1). Response surface methodology (RSM) with a Box-Behnken design was used for optimization of the processing parameters and to study the effect of individual factors and their interactive effects. Optimization was performed graphically, with contour and 3D model graphs used to indicate the optimal combination of processing parameters for maximization of banana juice yield. Significance level was set at $p<0.05$ for all factors in statistical analysis. The following second-order polynomial equation was developed to describe the relationship between dependent and independent variables:

$$
\begin{aligned}
Y= & b_{0}+b_{1} x_{1}+b_{2} x_{2}+b_{3} x_{3}+b_{12} x_{1} x_{2}+b_{13} x_{1} x_{3} \\
& +b_{23} x_{2} x_{3}+b_{11} x_{1}^{2}+b_{22} x_{2}^{2}+b_{33} x_{3}^{2}
\end{aligned}
$$

where $\mathrm{Y}$ is juice yield, $\mathrm{b}_{0}$ is the intercept, $\mathrm{b}_{1}, \mathrm{~b}_{2}$, and $\mathrm{b}_{12}$ are constant coefficients, and $\mathrm{x}_{1}, \mathrm{x}_{2}$, and $\mathrm{x}_{3}$ represents blending speed, extraction time, and stage of ripeness, respectively. 
Fig. 1 Categorization of different stages of ripeness in banana using a color index

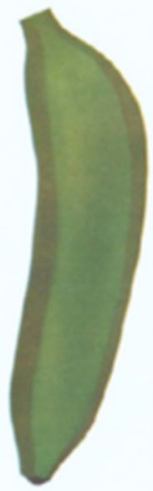

Category:

1

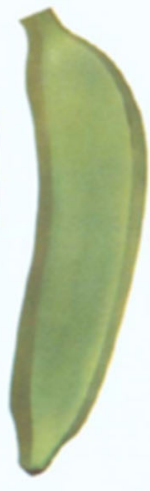

2

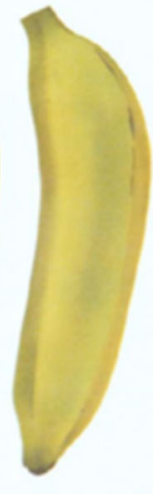

3

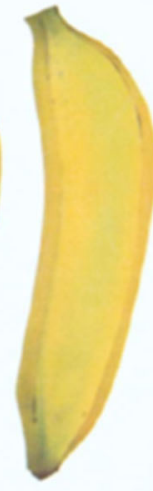

4

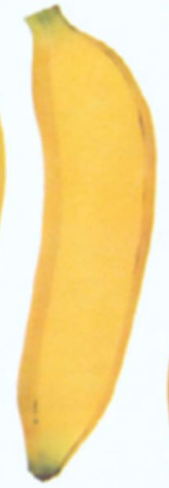

5

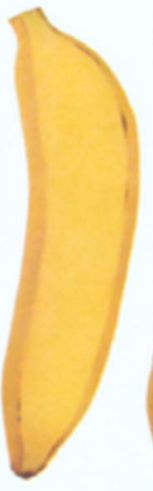

6

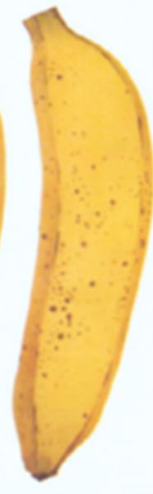

7

Table 1 Banana juice yield for combinations of the factors blending speed, extraction time, and ripeness index, each applied at three levels $(-1,0,+1$, shown in brackets), applied in randomized order in the 17 different runs in the experimental design

\begin{tabular}{lllllr}
\hline Randomized order & Run & Blending speed (rpm) & Extraction time (s) & Ripeness (index no.) & Yield (\%) \\
\hline 9 & 1 & $2250(0)$ & $135(0)$ & $5(0)$ & 57 \\
11 & 2 & $1000(-1)$ & $135(0)$ & $7(1)$ & 0 \\
12 & 3 & $1000(-1)$ & $135(0)$ & $3(-1)$ & 23 \\
5 & 4 & $3500(1)$ & $135(0)$ & $3(-1)$ & 34 \\
17 & 5 & $3500(1)$ & $135(0)$ & $7(1)$ & 0 \\
7 & 6 & $2250(0)$ & $135(0)$ & $5(0)$ & 52 \\
8 & 7 & $2250(0)$ & $240(1)$ & $7(1)$ & 0 \\
13 & 8 & $2250(0)$ & $135(0)$ & $5(0)$ & 55 \\
6 & 9 & $2250(0)$ & $30(-1)$ & $7(1)$ & 0 \\
3 & 10 & $3500(1)$ & $240(1)$ & $5(0)$ & 49 \\
14 & 11 & $3500(1)$ & $30(-1)$ & $5(0)$ & 38 \\
15 & 12 & $1000(-1)$ & $240(1)$ & $5(0)$ & 24 \\
16 & 13 & $1000(-1)$ & $30(-1)$ & $5(0)$ & 22 \\
1 & 14 & $2250(0)$ & $30(-1)$ & $3(-1)$ & 56 \\
4 & 15 & $2250(0)$ & $135(0)$ & $5(0)$ & 52 \\
2 & 16 & $2250(0)$ & $240(0)$ & $5(0)$ & 33 \\
10 & 17 & $2250(0)$ & $3(-1)$ & \\
\hline
\end{tabular}

\section{Results and discussion}

\section{Juice yield}

Banana juice yield ranged between 22 and $57 \%$ (Table 2). Similar results have been reported in previous studies, e.g., 58\% (Kibazohi et al. 2017), 53\% (Kyamuhangire 1990), $54.1 \%$ (Gensi et al. 1994), and 55.6\% (Gensi et al. 1994). However, those studies conducted a single-factor analysis, and thus did not determine interactive and quadratic effects of different factors.

As indicated in Table 2, stage of ripeness affected juice yield much more than the other two factors (blending speed, extraction time). The highest juice recovery was found for bananas at ripening stage 5 , while juice yield decreased with further ripening (stage 7) (Table 1). This agrees with previous findings of high juice recovery at stage 5 of ripening (Kibazohi et al. 2017). High juice recovery at stage 5 might be attributable to the presence of a high amount of soluble tannins (Kyamuhangire et al. 2006) and accumulation of protein (Tapre and Jain 2012). As described in previous studies, condensed tannins are likely involved in the formation of insoluble tannin-protein complexes, and this formation is favoured at high amounts of soluble tannins and proteins, resulting in enhanced release of juice (Ozdal et al. 2013; Naumann et al. 2014).

Analysis of variance (ANOVA) showed that all factors had a significant effect $(p<0.05)$ on juice yield, with linear and quadratic effects, but the interactive effect was non-significant (Table 2). The model described by Eq. (1) 
Table 2 Results of analysis of variance (ANOVA) for the quadratic model (Eq. 3)

\begin{tabular}{lllllc}
\hline Source & SS & DF & MS & F-value & $p$ value \\
\hline Model & 7117.06 & 9 & 790.78 & 74.10 & $<0.0001^{* * *}$ \\
A: Blending speed & 200.00 & 1 & 200.00 & 18.74 & $0.0034^{*}$ \\
B: Extraction time & 128.00 & 1 & 128.00 & 11.99 & $0.0105^{*}$ \\
C: Stage of ripeness & 1568.00 & 1 & 1568.00 & 146.93 & $<0.0001^{* * *}$ \\
AB & 0.2500 & 1 & 0.2500 & 0.0234 & 0.8827 \\
AC & 30.25 & 1 & 30.25 & 2.83 & 0.1361 \\
BC & 30.25 & 1 & 30.25 & 2.83 & 0.1361 \\
A $^{2}$ & 327.92 & 1 & 327.92 & 30.73 & $0.0009^{* * *}$ \\
$\mathrm{~B}^{2}$ & 366.13 & 1 & 366.13 & 34.31 & $0.0006^{* * *}$ \\
$\mathrm{C}^{2}$ & 4131.60 & 1 & 4131.60 & 387.16 & $<0.0001^{* * *}$ \\
Residual & 74.70 & 7 & 10.67 & & 0.1359 \\
Lack of fit & 53.50 & 3 & 17.83 & 3.36 & \\
C.V. & 10.50 & & & & \\
$\mathrm{R}^{2}$ & 0.9896 & & & & \\
Adjusted $\mathrm{R}^{2}$ & 0.9763 & & & & \\
Predicted $\mathrm{R}^{2}$ & 0.8764 & & & & \\
\hline
\end{tabular}

$S S$ sum of squares $D F$ degrees of freedom, $M S$ mean squares, $F$-value fisher value

*Significance at 0.05 level

**Significance at 0.01 level

***Significance at 0.001 level was significant $(p<0.05)$. The probability value for lack of fit was $p>0.05$, which indicates that the model adequately fit the actual data. In addition, it shows model suitability for prediction of variation patterns and thus can be used for design navigation. Coefficient of determination $\left(\mathrm{R}^{2}\right)$ for the predicted model was 0.8764 , i.e., only $12 \%$ of the total variation was not explained by the model (Baranyi et al. 1999; Ross 1996).

The independent variables were found to have a positive linear relationship with juice yield, but interactive and quadratic effects showed negative correlations to the yield, resulting in a curvilinear form of the model graphs:

$$
\begin{aligned}
\mathrm{Y}= & +54.60+5.00 \times \mathrm{A}+4.00 \times \mathrm{B}-14.00 \times \mathrm{C} \\
& +0.2500 \times \mathrm{AB}-2.75 \times \mathrm{AC}-2.75 \times \mathrm{BC}-8.83 \\
& \times \mathrm{A}^{2}-9.33 \times \mathrm{B}^{2}-31.32 \times \mathrm{C}^{2}
\end{aligned}
$$

where $\mathrm{Y}$ is juice yield, $\mathrm{A}$ is blending speed, B is extraction time, and $\mathrm{C}$ is stage of ripeness.

Since the interactive effect was not significant $(p>0.05)$ as indicated in ANOVA (Table 2), the secondorder polynomial model was reduced to only significant factors:

$\mathrm{Y}=+54.60+5.00 \times \mathrm{A}+4.00 \times \mathrm{B}-14.00 \times \mathrm{C}-8.93$

$$
\times \mathrm{A}^{2}-9.33 \times \mathrm{B}^{2}-31.32 \times \mathrm{C}^{2}
$$

The value of adjusted $\mathrm{R}^{2}(0.9763)$ was then close to that of $R^{2}(0.9896)$, indicating that removal of non-significant factors did not cause any distortion in model efficiency. Reliability of any experiment is measured by the coefficient of variation, where a higher value indicates low reliability (Kelley 2007; Romano et al. 2005). From the ANOVA results in Table 2, the coefficient of variation was 10.50 , indicating good reliability and precision of the experiments.

\section{Effect of blending speed, extraction time, and ripening stage on banana juice yield}

The effects of blending speed, extraction time, and ripening stage are represented in 3D graphs in Fig. 2a-c, where optimum values are within the darker (red) regions. As can be seen from the diagrams, juice yield increased non-linearly with the independent variables up to the optimum level. However, a decreasing trend in juice yield is evident beyond optimum conditions, which might be due to the quadratic nature of the model. Optimal juice yield was obtained at stage 5 of ripening, but over-ripening (ripeness stage 7) gave a reduction in juice yield. This is further explained by the negative coefficient of the quadratic effect in the model in Eq. (3). These results are in agreement with previous reports of juice failure with over-ripened bananas (Kibazohi et al. 2017; Kyamuhangire and Pehrson 1997, 1999). It is postulated that protein-tannin 


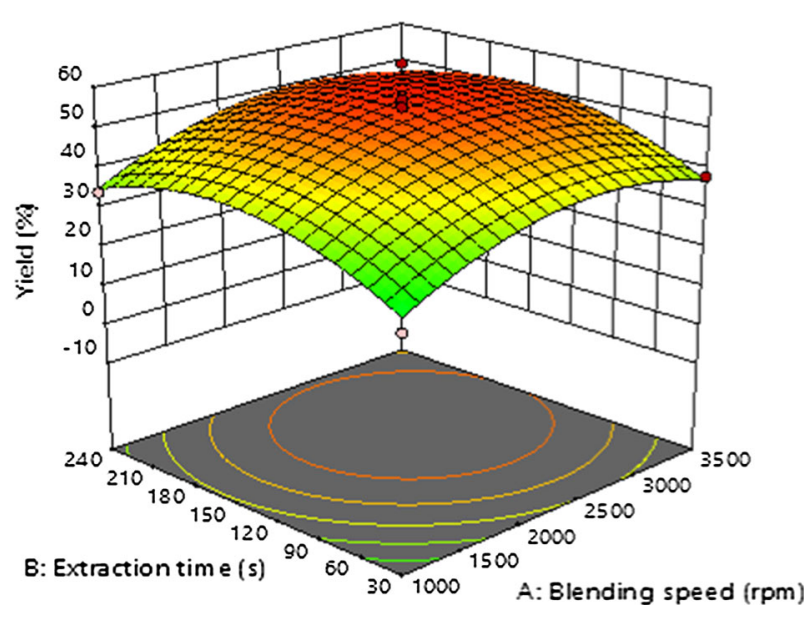

(a)

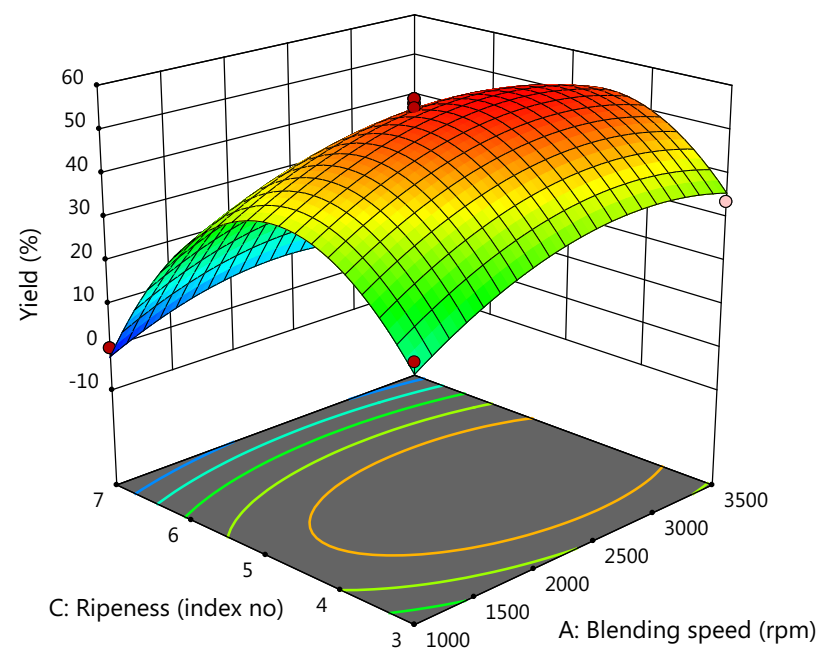

(c)

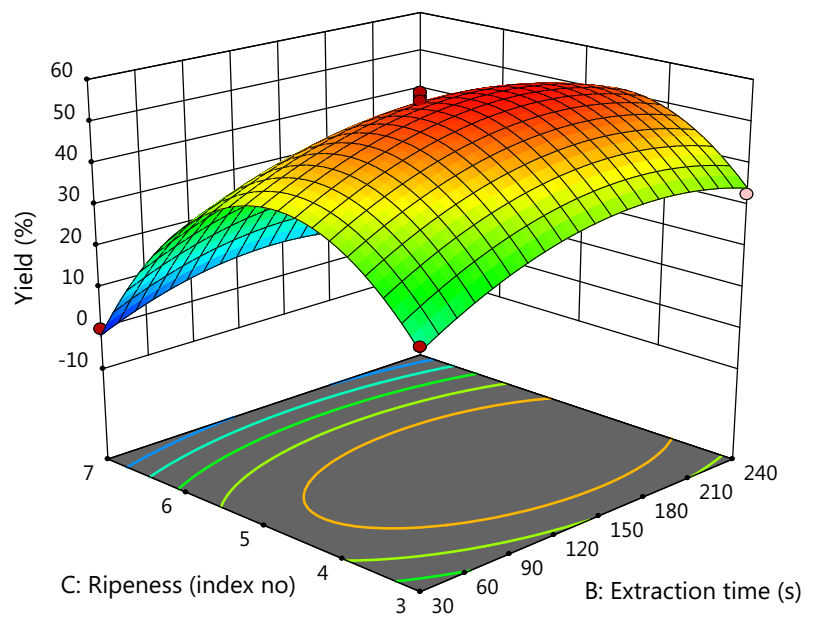

(b)

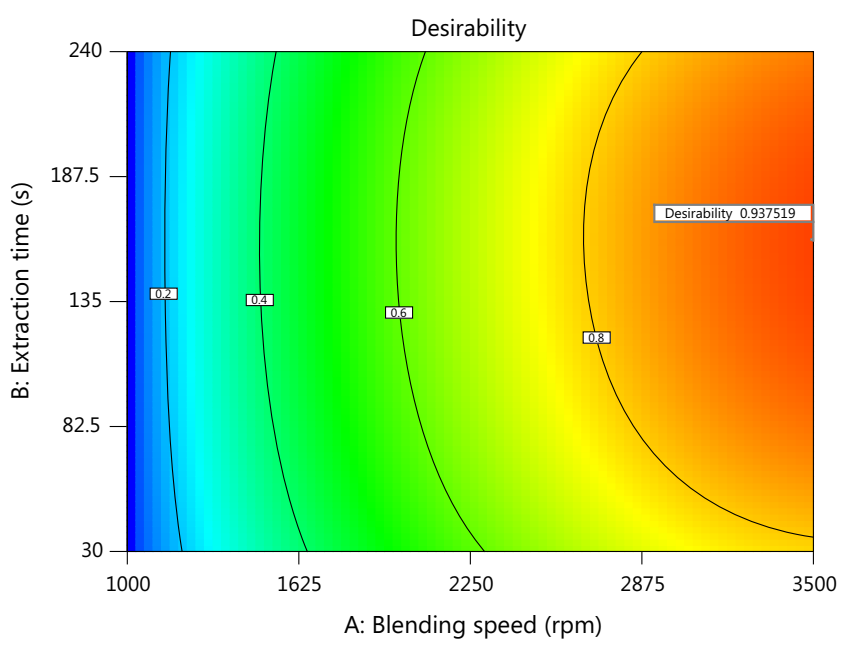

(d)

Fig. 2 a-c Response surface methodology diagrams for juice yield (\%) as a function of blending speed, extraction time and ripening stage. d Numerical optimization of juice yield

interactions are related to juice release in bananas (Kyamuhangire et al. 2006). Our results suggest that, as ripening proceeds above stage 5 , protein and tannin compounds previously involved in interactions undergo some biochemical changes that make their active sites unavailable for such interactions (Goldstein and Swain 1963; Kyamuhangire et al. 2006). As a result, juice failure occurs. Examination of the effect of extraction time and blending speed on juice yield at constant ripeness stage (Fig. 2a) showed that juice yield increased as extraction time increased from 30 to $162 \mathrm{~s}$, but with a further increase in extraction time (above $162 \mathrm{~s}$ ) juice yield decreased.

As mentioned, juice yield appeared to increase with ripening stage (i.e., 3-5), but further ripening (stage 7) decreased juice yield (Fig. 2b). As regards blending speed, juice yield increased to an optimum speed of $2650 \mathrm{rpm}$, while beyond that speed it decreased (Fig. 2c). At a low speed, the maximum blending time of $240 \mathrm{~s}$ was not enough for mechanical disruption of laticifer cells and to release tannins allowing interactions with proteins and the facilitation of juice release. Thus, with lower blending speed longer time is required to achieve higher yield.

\section{Model analysis}

As indicated in Fig. 3a, there is normality of the error term since the data follow a straight-line trend with no significant outliers, showing the relevance of the model. Studentized residuals are very good indicators of the presence or absence of outliers (Gomez and Gomes 1976; Raissi and Farsani 2009). Correlation of residuals and experimental runs are illustrated in Fig. 3b. There is no defined pattern 


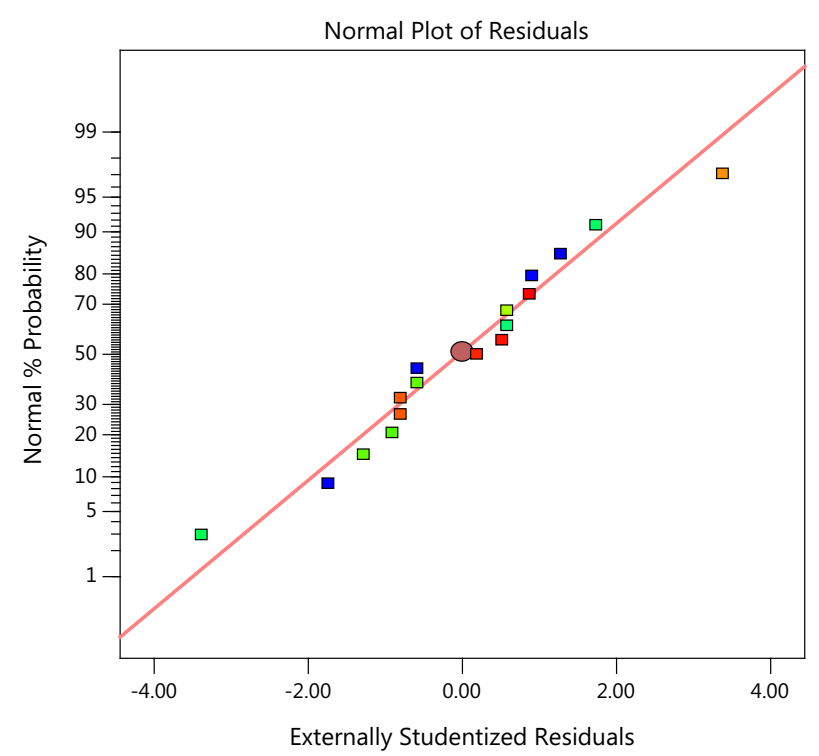

(a)

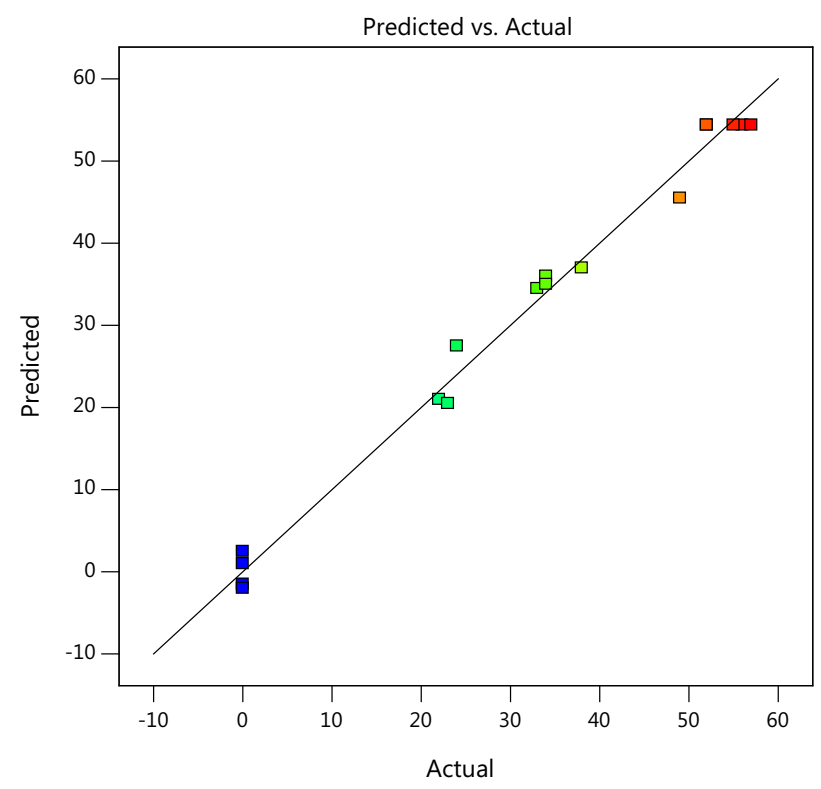

(c)

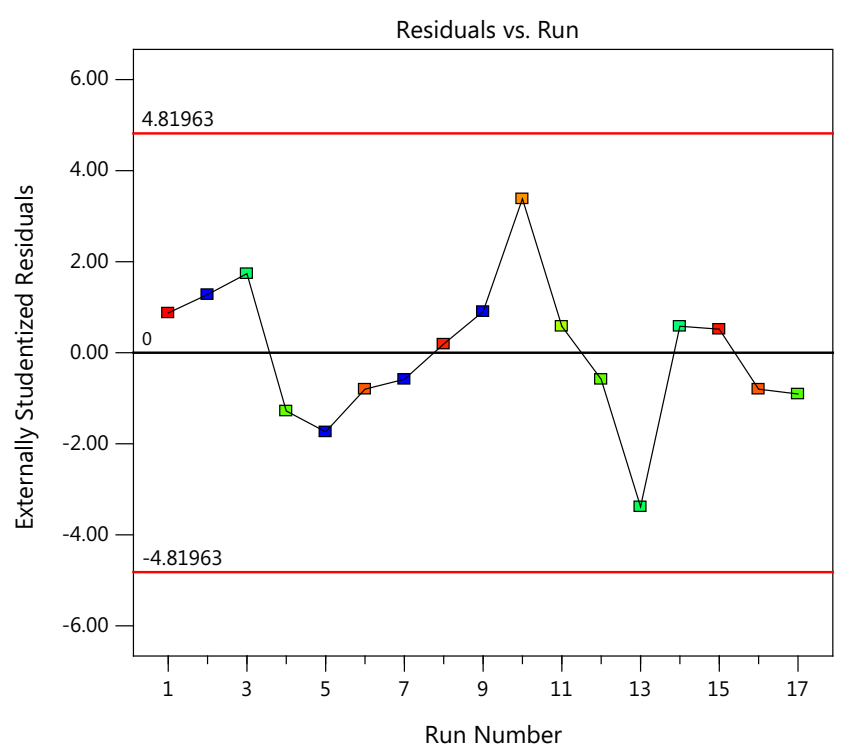

(b)

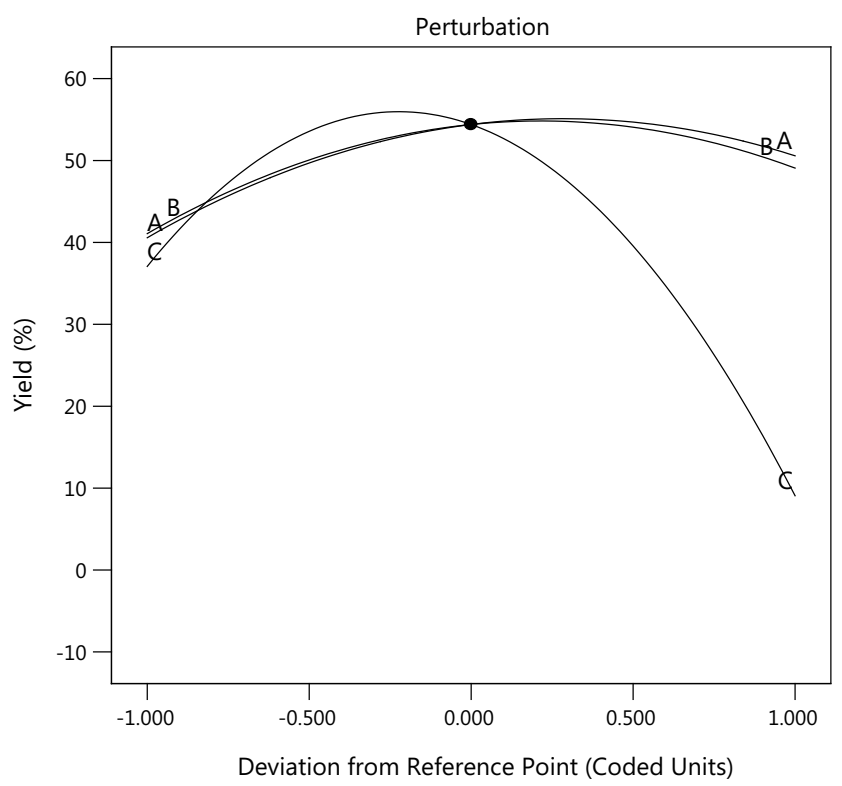

(d)

Fig. 3 a-c Analysis of model efficiency in maximization of juice yield. d Perturbation plot showing the effect of the independent variables on percentage yield of banana juice, where: $\mathrm{A}$ is blending speed, $\mathrm{B}$ is extraction time, and $\mathrm{C}$ is stage of ripeness

and points of experimental order are dispersed, suggesting that there is no lurking variable that is influencing the response variable. As shown in Fig. 3d, minor changes in ripeness stage can lead to great changes in yield, whereas minor changes in blending speed and extraction time gave only slight changes in yield. As a result, the curve for ripeness is steeper than that of the other factors.

\section{Process optimization}

The processing parameters were optimized numerically using the desirability function in design expert software for maximization of yield. The values obtained for optimum production of banana juice were: a blending speed of $2655 \mathrm{rpm}$, an extraction time of $162 \mathrm{~s}$, and stage 5 of ripening. Desirability shows the interval between the response and its ideal value, and its value usually falls within the range 0-1 (Raissi and Farsani 2009). As can be 
Table 3 Difference between actual values of banana juice yield in four runs in the experiment and the corresponding values predicted by the model described by Eq. (3)

\begin{tabular}{llll}
\hline Run no. & Actual yield $(\%)$ & Predicted yield $(\%)$ & Difference $(\%$ units) \\
\hline 5 & 34 & 35.8 & 1.8 \\
13 & 55 & 54.3 & 0.7 \\
15 & 34 & 34.7 & 0.7 \\
10 & 33 & 34.2 & 1.2 \\
\hline
\end{tabular}

seen from the optimum graph (Fig. 2d), the desirability value was 0.937 , which is near to the ideal value (1).

\section{Verification and validation of the model}

Verification and validation was performed to check the significance of the model in predicting the response variable. Four runs $(5,13,15$, and 10) from the 17 runs used in the experimental design matrix (see Table 1) were used for verification, as shown in Table 3. Using the model described by Eq. (3), the predicted value was determined. There was only a slight difference between the experimental and predicted values, which suggests that the model is valid.

\section{Conclusion}

Response surface methodology (RSM) was used to determine the optimum process variables (blending speed, extraction time, stage of ripeness) for mechanical extraction of banana juice. The model developed for prediction of processing parameters was significant $(p<0.001)$, which implies that it is suitable for navigation of design space. A second order polynomial equation showed that juice extraction is significantly affected by blending speed, extraction time, and stage of ripeness. The desirability value obtained was 0.937 , showing that the setting of the independent variables in optimizing the yield was good. The optimum conditions, determined as the highest juice yield $(57.5 \%$ ), were a blending speed of $2650 \mathrm{rpm}$, an extraction time of $162 \mathrm{~s}$, and stage 5 of banana ripeness. Degree of ripeness was identified as the most important factor, as it exerted a highly significant effect $(p<0.001)$ on the response variable. Production of banana juice using the optimum values of these three physical parameters will reduce the production costs and maximize the juice yield, which in turn will enable scaling-up and commercialization of the process. However, further studies are needed to validate the model in prediction of physical parameters for different banana cultivars and larger blender sizes.

Acknowledgements The financial support of the Swedish International Development Cooperation Agency (SIDA) under the program "Sustainable Agricultural Productivity, Processing and Value Chain for Enhancing Food security in Tanzania" is gratefully acknowledged.

\section{Compliance with ethical standards}

Conflict of interest The authors declare that they have no conflict of interests.

\section{References}

Adeniji TA, Tenkouano A, Ezurike JN, Ariyo CO, Vroh-Bi I (2010) Value-adding post harvest processing of cooking bananas (Musa spp. $\mathrm{AAB}$ and $\mathrm{ABB}$ genome groups). Afr $\mathrm{J}$ Biotechnol 9:9135-9141

Affognon H, Mutungi C, Sanginga P, Borgemeister C (2015) Unpacking postharvest losses in sub-Saharan Africa: a metaanalysis. World Dev 66:49-68. https://doi.org/10.1016/j.world dev.2014.08.002

Baranyi J, Pin C, Ross T (1999) Validating and comparing predictive models. Int J Food Microbiol 48:159-166. https://doi.org/10. 1016/S0168-1605(99)00035-5

Byarugaba-Bazirake G (2008) The effect of enzymatic processing on banana juice and wine. $\mathrm{PhD}$ thesis, Stellenbosch University, Stellenbosch. https://scholar.sun.ac.za/handle/10019.1/1320. Accessed 7 Aug 2017

Gensi R, Kyamuhangire W, Carasco JF (1994) Traditional production and characteristic of banana juice in Uganda. In: African Crop Science conference proceedings, vol 1, pp 356-359 (Uganda)

Goldstein T, Swain J (1963) Changes in Tannins. In: Robins R (ed) Phytochemistry, vol 2. Pergamon Press Ltd, England, pp 371-383

Gomez A, Gomes A (1976) Statistical procedures for agricultural research with emphasis on rice. Wiley, New York

Ibarra-Junquera V, Escalante-Minakata P, Chávez-Rodríguez AM, Comparan-Dueñas IA, Osuna-Castro JA, de Ornelas-Paz J, Aguilar CN (2014) Optimization, modeling, and online monitoring of the enzymatic extraction of banana juice. Food Bioproc Technol 7:71-83. https://doi.org/10.1007/s11947-013-1136-2

Kelley K (2007) Sample size planning for the coefficient of variation from the accuracy in parameter estimation approach. Behav Res Methods 39:755-766. https://doi.org/10.3758/BF03192966

Kibazohi O, Kyamuhangire W, Kaunga DL, Rokoni C (2017) Process improvement for mechanical extraction of low-viscosity clear banana juice. Afr J Food Sci 11:291-295. https://doi.org/10. 5897/AJFS2017.1604

Kumar S (2015) Role of enzymes in fruit juice processing and its quality enhancement. Adv Appl Sci Res 6:114-124

Kyamuhangire W (1990) Banana juice extraction and processing. $\mathrm{PhD}$ thesis, University of New South Wales, Kensington

Kyamuhangire W (1998) Technological aspects of the mechanical extraction of banana juice. Doctor Scientiarum Thesis, Agricultural University of Norway, Norway

Kyamuhangire W, Pehrson R (1997) Adaptation of the traditional banana juice extraction technology to a mechanical process and 
factors influencing juice release. In: II international symposium on banana: I international symposium on banana in the subtropics, vol 490, pp 577-584 (Spain)

Kyamuhangire W, Pehrson R (1999) Conditions in banana ripening using the rack and pit traditional methods and their effect on juice extraction. J Sci Food Agric 79:347-352. https://doi.org/10. 1002/(SICI)1097-0010(199902)79

Kyamuhangire W, Myhre H, Sørensen HT, Pehrson R (2002) Yield characteristics and composition of banana juice extracted by the enzymatic and mechanical methods. J Sci Food Agric 4:478-482. https://doi.org/10.1002/jsfa.1052

Kyamuhangire W, Krekling T, Reed E, Pehrson R (2006) The microstructure and tannin content of banana fruit and their likely influence on juice extraction. J Sci Food Agric 12:1908-1915. https://doi.org/10.1002/jsfa.2553

Landbo AK, Kaack K, Meyer AS (2007) Statistically designed two step response surface optimization of enzymatic prepress treatment to increase juice yield and lower turbidity of elderberry juice. Innov Food Sci Emerg Technol 8:135-142. https://doi.org/ 10.1016/j.ifset.2006.08.006

Lee WC, Yusof S (2006) Optimizing conditions for hot water extraction of banana juice using response surface methodology (RSM). J Food Eng 75:473-479. https://doi.org/10.1016/j. jfoodeng.2005.04.062

Mohapatra D, Mishra S (2011) Post-harvest processing of banana: opportunities and challenges. Food Bioproc Technol 4:327-339. https://doi.org/10.1007/s11947-010-0377-6

Mohapatra D, Mishra S, Sutar N (2010) Banana and its by-product utilisation: an overview. Pak J Sci Ind Res Pak 69:323-329

Naumann H, Hagerman A, Lambert B, Muir J, Tedeschi L, Kothmann M (2014) Molecular weight and protein-precipitating ability of condensed tannins from warm-season perennial legumes. J Plant Interact 9:212-219. https://doi.org/10.1080/17429145.2013.811547

Net F (2018) Market Fundamentals Summary. http://fews.net/sites/ default/files/documents/reports/Tanzania_MFR_Summary_ Report_August_2018.pdf. Accessed 26 Nov 2018

Ozdal T, Capanoglu E, Altay F (2013) A review on protein-phenolic interactions and associated changes. Food Res Intl 51:954-970. https://doi.org/10.1016/j.foodres.2013.02.009
Palmer JK (1979) Tropical foods: chemistry and nutrition. Academic Press, Inc., New York

Pedersen EK (2012) Factors affecting the adoption of improved banana technologies in Northern Tanzania. https://www.rock woolfonden.dk/app/uploads/2015/12/Banana-Spreading-evalua tion-note.pdf. Accessed 8 Oct 2017

Raissi S, Farsani RE (2009) Statistical-process-optimization-throughmulti-response-surface-methodology. Int J Math Sci 3:197-201

Romano FL, Ambrosano GMB, de Magnani MBB, Nouer DF (2005) Analysis of the coefficient of variation in shear and tensile bond strength tests. J Appl Oral Sci 13:243-246

Ross $\mathrm{T}$ (1996) Indices for performance evaluation of predictive models in food microbiology. J Appl Bacteriol 81:501-508. https://doi.org/10.1111/j.1365-2672.1996.tb03539.x

Sagu ST, Nso EJ, Karmakar S, De S (2014) Optimisation of low temperature extraction of banana juice using commercial pectinase. Food Chem 151:182-190. https://doi.org/10.1016/j. foodchem.2013.11.031

Tapre AR, Jain RK (2012) Study of advanced maturity stages of banana. Int J Adv Eng Res Stud 1:272-274

Tapre AR, Jain RK (2014) Pectinases: enzymes for fruit processing industry. Int Food Res J 21:447-453

Trust K (2012) Analysis of the banana value chains in Tanzania and Uganda and challenges. https://www.kilimotrust.org/Publica tion-Banana VCA Report production consumption and challenges. Accessed 18 July 2017

USDA (2001) Banana Visual Aid. https://www.ams.usda.gov/sites/ default/files/media/Bananas_Visual_Aid\%5B1\%5D.pdf. Accessed 27 Aug 2018

Viquez F, Lastreto C, Cooke RD (1981) A study of the production of clarified banana juice using pectinolytic enzymes. J Food Technol 2:115-125

Publisher's Note Springer Nature remains neutral with regard to jurisdictional claims in published maps and institutional affiliations. 